Check for updates

New York, USA

Cite this as: BMJ 2021;372:n246 http://dx.doi.org/10.1136/bmi.n246 Published: 27 January 2021

\section{Covid-19: Biden buys 200 million doses of vaccines to tackle supply shortages across US}

\author{
Janice Hopkins Tanne
}

President Joe Biden announced on 26 January that he had purchased 200 million more doses of the two authorised vaccines -100 million doses of the Pfizer BioNTech vaccine and 100 million doses of the Moderna vaccine-for what he called a "wartime effort to tackle the supply shortages we inherited from the previous administration." ${ }^{1}$

At the same time he warned that the death toll from the virus might be half a million by the end of February. ${ }^{2}$

The Biden administration said that beginning next week it would increase by $16 \%$ the supply of vaccines distributed to states, tribes, and territories from 8.6 million doses per week to a minimum of 10 million doses, allowing more people to get vaccinated sooner than previously anticipated. It said that it would maintain this as a minimum supply level for the next three weeks with the supply expected to increase in late March. The recipient states, tribes, and territories will now get three weeks' notice of what deliveries to expect, instead of the previous one week, to improve planning.

The new supply, with the vaccine doses already ordered for delivery by the end of June, will increase the nation's supply to 600 million doses. That is enough to fully vaccinate 300 million Americans with the two dose regimen by the end of the summer. The US has a population of about 330 million. Vaccines are currently recommended for people older than 16 or 18.

Shortages have led many states to close vaccine facilities and cancel or postpone vaccine appointments.

When Rochelle Walensky took over as head of the Centers for Disease Control and Prevention (CDC) she said she didn't know how much vaccine the nation had and therefore couldn't tell governors and state officials how to plan for distribution. Now, she said, she expected the vaccine supply to increase dramatically by late March. The CDC had been "muzzled" under the Trump administration, she said, and her job was to restore trust. ${ }^{3}$

Michael Osterholm, an infectious diseases expert at the University of Minnesota and a Biden adviser, said, "There was no plan by the Trump administration in terms of distribution, or how to talk to the public about these vaccines and educate people about why they're so important to their health," He praised the Biden administration for its national plan to respond to the pandemic. ${ }^{4}$

The Biden administration has a long way to go. Some 44 million vaccine doses have been distributed to date but only 3.5 million people-about $1 \%$ of the population-have been fully vaccinated. Nearly 20 million people have received one or both doses of the vaccine. ${ }^{5}$

As Biden had promised, at least one million people have been receiving the vaccine every day. Most states have followed guidelines from the CDC and are prioritising healthcare workers and residents and staff of nursing homes, followed by essential workers such as first responders, teachers, day care staff, grocery store workers, and the elderly.

States have varied in their success in vaccinating their populations. Several small states (by population) have done best in fully vaccinating their populations: West Virginia has fully vaccinated $2.4 \%$ of its population, Alaska 2.3\%, North Dakota and South Dakota $2.1 \%$, and New Mexico 1.7\%. States with large populations-California, Florida, New York, and Texas-have fully vaccinated only $1 \%$.

Sanofi has announced that it is joining with Pfizer and BioNTech to help produce its mRNA covid-19 vaccine. ${ }^{6}$ Johnson and Johnson is also preparing to release data on its phase III trial for its one dose vaccine and hopes for Food and Drug Administration authorisation. ${ }^{7}$ Regeneron is in a phase III trial of its "antibody cocktail" that it said was effective in preventing covid-19 symptoms compared with placebo. ${ }^{8}$

Fact sheet: President Biden announces new steps to boost vaccine supply and increase transparency for states, tribes, and territories. Whitehouse.gov. 26 January 2021. www. whitehouse.gov/briefing-room/statements-releases/2021/01/26/fact-sheet-president-biden-announces-new-steps-to-boostvaccine-supply-and-increase-transparency-for-states-tribes-and-territories.

2 Stolberg G, Weiland N, LaFraniere S. Biden pledges to speed flow of vaccines to states. New York Times. 26 January 2021. www.nytimes.com/2021/01/26/us/politics/biden-coronavirus-vaccines.html.

3 CDC director predicts covid-19 vaccine distribution will increase dramatically by late March. Fox News Sunday. 24 January 2021. www foxnews.com/transcript/cdc-director-predicts-covid-19-vaccine-distribution-will-increase-dramatically-by-late-march.

4 Trump administration had "no plan" for covid-19 vaccine distribution, Dr Michael Osterholm says. WBUR. 21 January 2021. www.wbur.org/hereand now/2021/01/21/biden-covid-19-osterholm.

5 At least 19.9 million people have received one or both doses of the vaccine in the US. Washington Post. 26 January 2021. www.washingtonpost.com/graphics/2020/health/covid-vaccine-states-distribution-doses.

6 Sagonowsky I. Sanofi, after R\&D setback, lends a hand to vaccine rival Pfizer for coronavirus shot production. Fierce Pharma. 26 January 2021. www.fiercepharma.com/pharma/sanofi-after-r-d-setback-lends-a-hand-tovaccine-rival-pfizer-for-coronavirus-shot.

7 Sagonowsky E. Johnson \& Johnson is "comfortable" meeting coronavirus vaccine delivery program, CFO promises. Fierce Pharma. 26 January 2021. www.fiercepharma.com/pharma/sanofi-after-r-d-setback-lends-a-hand-tovaccine-rival-pfizer-for-coronavirus-shot.

8 Weintraub A. Regeneron pitches covid-19 antibody cocktail for 'passive vaccination' with fresh trial data. Fierce Pharma. 26 January 2021. www.fiercepharma.com/pharma/regeneron-pitches-covid-antibody-cocktailfor-passive-vaccination-fresh-trial-data. 